\title{
Wood dynamics in headwater streams of the Colorado Rocky Mountains
}

\author{
Ellen Wohl ${ }^{1}$ and Jaime R. Goode ${ }^{1}$ \\ Received 13 September 2007; revised 22 May 2008; accepted 27 June 2008; published 20 September 2008. \\ [1] An 11-year monitoring study begun in 1996 evaluates wood mobility in five Colorado \\ Rocky Mountain streams. Each channel reach is $40-70 \mathrm{~m}$ in length. Initial surveys \\ included channel dimensions and arrangement of each piece of wood. Annual resurveys \\ focused on wood arrangement and persistence. Average diameter of $15 \mathrm{~cm}$ and length \\ of $3.2 \mathrm{~m}$ varied little among sites. Average yearly mobility ranged from $16 \%$ to $23 \%$. \\ Average residence time was 3.4 years. Wood load correlates positively with valley width \\ and channel gradient, and negatively with relative substrate submergence and mean \\ annual peak discharge. Survival analysis revealed that individual piece residence time was \\ controlled by a nondimensional piece length and peak unit stream power during the \\ year of removal. Residence time increases as piece length relative to channel width \\ decreases, which could be explained by a greater integration of the flow field for longer \\ pieces. Mobility of individual pieces of wood is controlled primarily by piece \\ characteristics (length, diameter, type). Likelihood of mobility is smallest for buried \\ pieces. The brevity of residence time relative to studies from other regions likely results \\ from relatively low wood loads in these channels after timber harvesting cleared both \\ instream and riparian wood supply more than a century ago. Although individual pieces \\ of wood are exchanged, wood load and the location of individual logjams remain \\ relatively constant.
}

Citation: Wohl, E., and J. R. Goode (2008), Wood dynamics in headwater streams of the Colorado Rocky Mountains, Water Resour. Res., 44, W09429, doi:10.1029/2007WR006522.

\section{Introduction}

[2] An extensive literature documents the geomorphic and ecological roles of wood in streams from steep headwater channels to large, low-gradient rivers around the world. Within the United States, the majority of studies come from the Pacific Northwest, where investigators have focused on how wood influences hydraulics [MacFarlane and Wohl, 2003], transport and storage of sediment and organic matter [Bilby and Ward, 1989; Abbe and Montgomery, 1996; Faustini and Jones, 2003; Montgomery et al., 2003a, 2003b], avulsion and braiding [Collins et al., 2002], floodplain dynamics [Brummer et al., 2006; Montgomery and Abbe, 2006], and habitat for aquatic organisms [Bisson et al., 1987; Carlson et al., 1990; Fausch and Northcote, 1992; Jackson and Sturm, 2002].

[3] A substantial gap in our knowledge of wood in streams comes from the lack of studies directly examining wood dynamics, the mobility and retention of wood within a stream, over periods longer than a year or two. Estimates of wood dynamics can be based on the age of "nursed" trees that subsequently grew on the fallen wood, on direct observations over some time span, or on studies of relative mobility as a function of wood size, shape, arrangement in

\footnotetext{
${ }^{1}$ Department of Geosciences, Colorado State University, Fort Collins, Colorado, USA.

Copyright 2008 by the American Geophysical Union. 0043-1397/08/2007WR006522
}

the stream, or stream characteristics. Investigators using the age of nursed trees have documented residence times from 20 to 220 years for wood in the Pacific Northwest and southeastern Alaska, with much of the wood being retained for decades [Hyatt and Naiman, 2001]. Studies using direct monitoring of tagged pieces of wood in selected stream segments tend to be of short duration (Table 1), with two exceptions. Lienkaemper and Swanson [1987] studied five streams in Oregon over a 7-9 year period and estimated residence times as long as 83 years for the small streams they studied, and as short as 12 years for the largest stream. Although not expressed in terms of residence time, an ongoing study of wood in Oregon's Mack Creek that was begun in 1986 found that no more than $10 \%$ of the wood was redistributed in any year, with less than $1 \%$ of the pieces moving in most years [Gregory, 1991; Gurnell et al., 2002]. As noted by Berg et al. [1998], the lack of common standards for the minimum size of pieces tagged and streamflow magnitudes examined makes it difficult to quantitatively compare the results of various field studies.

[4] In these studies, residence time refers to the length of time that a discrete piece of wood remains in one location within a stream. Residence time can also refer to retention time within a stream or channel network as a whole, or to the time that large wood pieces $(>10 \mathrm{~cm}$ wide and $1 \mathrm{~m}$ long) are retained within the stream before being broken down into smaller pieces. Mobility is commonly used to describe the transport of discrete pieces of wood and, using the first definition of residence time given above, would be inversely 


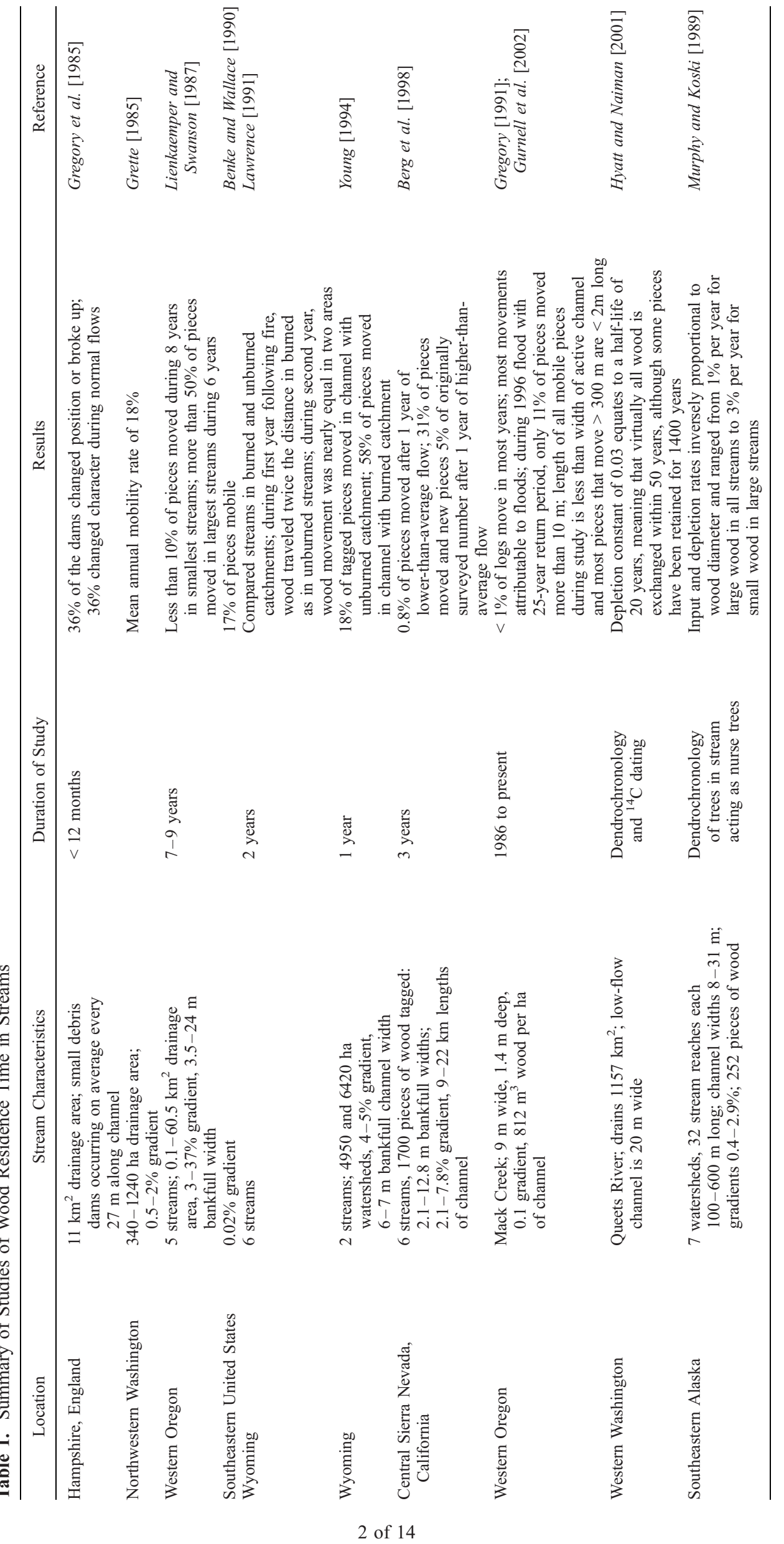


proportional to residence time under conditions in which transport, rather than decay in situ, dominates residence time.

[5] Studies of relative mobility in both field and flume settings indicate that, within a given sample of wood, pieces that are longer and have a larger diameter tend to be more stable [Young, 1994; Berg et al., 1998; Gurnell et al., 2002; Bocchiola et al., 2006a, 2006b], as do pieces that are at least partially buried in the streambed [Berg et al., 1998], that are oriented parallel to the flow [Braudrick and Grant, 2000], or are stabilized by other logs in a jam [Gurnell et al., 2002]. Magnitude and sequence of flows partially control wood dynamics [Haga et al., 2002], and wood is more likely to move during floods [Gurnell et al., 2002; Bocchiola et al., 2006a, 2006b] and in larger streams [Lienkaemper and Swanson, 1987].

[6] The limited number of studies of wood dynamics prevents much extrapolation beyond generalizations about relative piece mobility as a function of wood size, shape, and position within the channel network. We do not yet have sufficient field data to quantitatively estimate residence time of a piece of wood introduced to a stream, especially in streams outside of the Pacific Northwest, where most studies of wood retention have been conducted. Given the well-documented geomorphic and ecological functions of wood across a range of streams, scientists and resource managers are sometimes asked to specify levels of wood load, as well as channel stability and associated residence time of wood, which would constitute a "natural" or "healthy" stream condition that might provide a management target.

[7] It is within this context that this study was undertaken to quantify residence times of wood in five streams of the Colorado Rocky Mountains. Although fewer investigators have examined wood in Rocky Mountain streams, their work has documented geomorphic and ecological roles for wood similar to those in the Pacific Northwest [Heede, 1972; Malanson and Butler, 1990; Young, 1994; Richmond and Fausch, 1995; Wohl et al., 1997; Marcus et al., 2002; Fausch and Young, 2004; Zelt and Wohl, 2004]. One of the consistent differences between the regions is that total volume of wood is much less in streams of the Rocky Mountains. Richmond and Fausch [1995] report that wood volumes average $13 \mathrm{~m}^{3}$ per $100 \mathrm{~m}$ of stream in the Colorado Rockies versus $58 \mathrm{~m}^{3}$ in Alaska and $43 \mathrm{~m}^{3}$ in British Columbia, for example, although multiple factors influence wood volume and these comparisons are based on limited sample sizes. Because the volume of wood can influence the manner of transport [Braudrick et al., 1997] and the mobility of the wood, lower wood volumes in Rocky Mountain streams could potentially correlate with different residence times than those observed in the Pacific Northwest.

[8] This paper presents the first direct observations published on residence time over a period of several years along snowmelt-dominated headwater streams in mountains of the semiarid interior western United States. Our intent was to isolate the temporal component of LWD dynamics and determine the controls on piece residence time. The movement of pieces of wood was monitored annually during 1996-2006 along five study reaches in order to examine residence time of each piece and potential controls on residence time. We use residence time to refer to the length of time that a discrete piece of wood remains intact and in one location within a study reach. We expected that residence time would be a function of individual piece characteristics (dimensions, type and number of pieces in contact) and hydraulic characteristics (peak discharge and unit stream power); specifically, we expected that longer pieces or those partially attached to the bed or banks would have a longer residence time, and that residence time would be greater in streams with less hydraulic force and during years of lower peak discharge. We expected that wood along these relatively small streams in a semiarid region would move infrequently $(<10 \%$ of pieces mobile each year) in the absence of major disturbances such as debris flows or exceptionally large snowmelt floods, based partly on the results from Lienkaemper and Swanson [1987], Gregory [1991], and Gurnell et al. [2002]. Given the relative consistency of snowmelt in these streams, we expected that piece characteristics would be the dominant control on the likelihood of mobility and residence time.

\section{Study Area}

[9] Five stream reaches in the central Rocky Mountains of Colorado were selected for this study (Figure 1). All of the sites are underlain by Precambrian crystalline rocks (granitic, gneisses, and schists) [Tweto, 1979]. Site elevations range from $2960 \mathrm{~m}$ to $2740 \mathrm{~m}$, and catchments are covered in subalpine forest of Engelmann spruce (Picea engelmannii), subalpine fir (Abies lasiocarpa), and lodgepole pine (Pinus contorta). Snowmelt runoff dominates flow regimes, producing an annual peak flow in mid-late June. Only the site at East St. Louis Creek has a nearby gaging station. Base flow at this gage averages $0.03 \mathrm{~m}^{3} / \mathrm{s}$ and annual peak averages $0.58 \mathrm{~m}^{3} / \mathrm{s}$, with a maximum recorded peak of $1.84 \mathrm{~m}^{3} / \mathrm{s}$ in 1957 . Step-pool sequences and straight channels with stable banks characterize channel morphology at all of the study sites. Characteristics of each reach are summarized in Table 2. The length of each reach is approximately ten times the average channel width. Each of the study reaches was in a relatively confined valley bottom in which valley-bottom width was less than twice the width of the active channel. Lateral channel movement, overbank flooding, floodplain development, and storage of wood within the floodplain or low terraces are limited along the study reaches.

[10] Stream reaches selected are upstream from land-use disturbances such as roads and flow regulation, and the catchment above each reach has not had timber harvest in approximately a century. Portions of the catchment surrounding Ouzel Creek burned in 1977, and woody vegetation has been slow to regrow at this dry, high-elevation site (Figure 2a). A beaver dam associated with a lodge that had been abandoned within the previous few months was present at Loch Vale Creek at the start of the study in 1996, and beavers did not reoccupy the site during the remainder of the study duration. Hillslope mass movements that might introduce wood to the channel did not occur at any of the study sites during the study period, and there was no evidence of such mass movements within the past few decades at the sites. No tributaries enter any of the study reaches. Consequently, wood introduced to the study rea- 


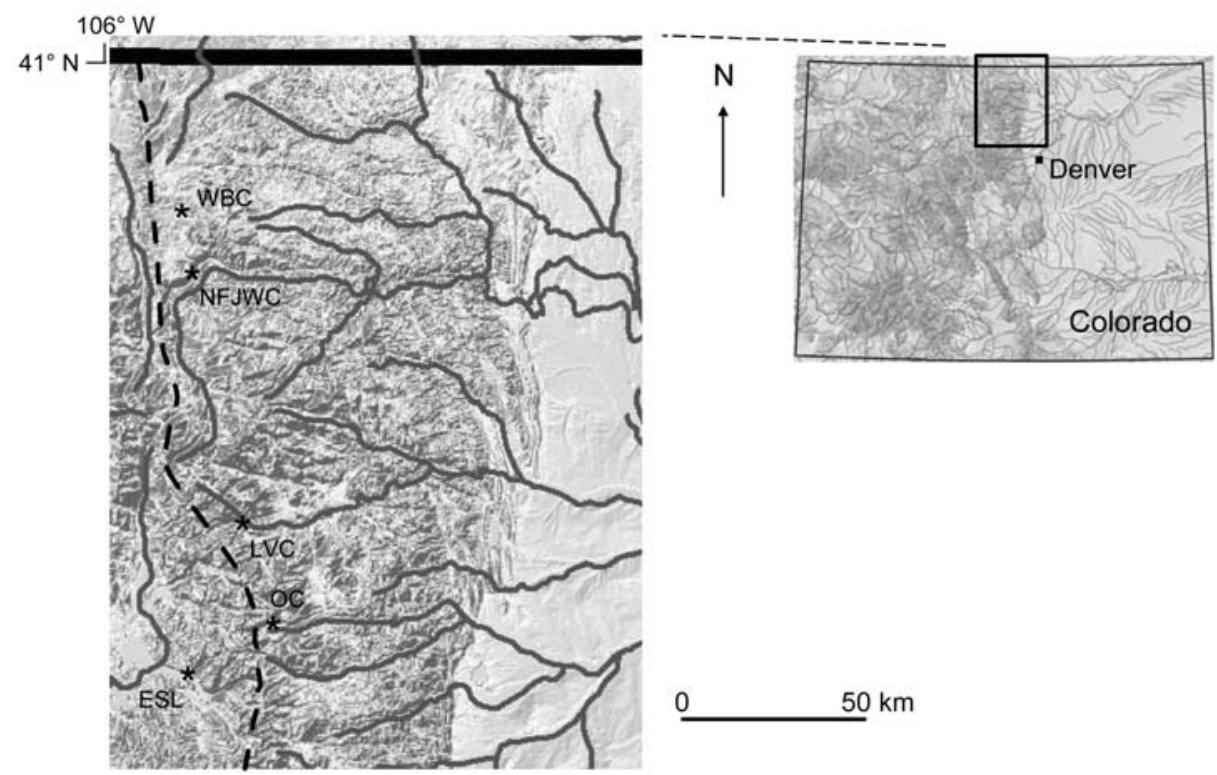

Figure 1. Stars indicate locations of the five study sites in the northern Colorado Rocky Mountains. From north to south: West Branch Creek (WBC), North Fork Joe Wright Creek (NFJWC), Loch Vale Creek (LVC), Ouzel Creek (OC), and East St. Louis Creek (ESL). Dashed vertical line is the Continental Divide.

ches must come from upstream transport or via tree fall from the adjacent riparian zone.

\section{Methods}

\subsection{Field Methods}

[11] Annual surveys of wood were conducted in late summer or early autumn, at the lowest discharges before snow and ice covered each channel for the winter. Minimum piece size for wood to be measured was $1 \mathrm{~m}$ in length and 5 $\mathrm{cm}$ in diameter; wood had to meet both minimum criteria to be included. Field work began in 1996 and continued through 2006, allowing us to assess changes in wood load over 10 annual increments.

[12] Variables measured at each field site include the catchment parameters drainage area $(A)$ and elevation $(E)$, which were measured from 7.5-min topographic quadrangles. Valley parameters include width of the valley bottom $\left(w_{v}\right)$, average diameter at breast height of trees within $50 \mathrm{~m}$ of each side of the active channel $(D B H)$, and spatial density of standing trees within $50 \mathrm{~m}$ of each side of the active channel (tree $\rho$ ). Fifty meters was chosen as a width for the zone from which wood could potentially be recruited to channel through tree fall because trees in the study area are all less than $50 \mathrm{~m}$ in height.

[13] Channel parameters include hydraulic variables, channel geometry, and wood characteristics. All hydraulic and channel geometry variables were measured or calculated for the estimated mean annual snowmelt peak flow, which we refer to as the reference discharge. On these mostly ungaged channels, we inferred the stage of the reference discharge from a break in slope along the bank and a change in vegetation. In order to facilitate the calculation of hydraulic variables associated with flow at this reference stage, we measured reach-averaged flow velocity $(v)$ at the snowmelt peak during one year of the study using a salt

Table 2. Characteristics of the Study Sites

\begin{tabular}{|c|c|c|c|c|c|c|c|c|c|c|c|c|c|c|c|}
\hline \multirow[b]{2}{*}{ Stream } & \multirow[b]{2}{*}{$\begin{array}{c}A^{\mathrm{a}} \\
\left(\mathrm{km}^{2}\right)\end{array}$} & \multirow[b]{2}{*}{$\begin{array}{c}S \\
(\mathrm{~m} / \mathrm{m})\end{array}$} & \multirow[b]{2}{*}{$\begin{array}{l}w_{v} \\
(\mathrm{~m})\end{array}$} & \multirow[b]{2}{*}{$\begin{array}{l}w \\
(\mathrm{~m})\end{array}$} & \multirow[b]{2}{*}{$\begin{array}{l}\mathrm{D}_{50}(\mathrm{~mm}) \\
\mathrm{D}_{84}(\mathrm{~mm})\end{array}$} & \multirow{2}{*}{$\begin{array}{l}\text { Reach } \\
\text { Length } \\
\text { (m) }\end{array}$} & \multirow[b]{2}{*}{$R / D_{84}$} & \multicolumn{3}{|c|}{ Wood Load ${ }^{\mathrm{b}}$} & \multirow{2}{*}{$\begin{array}{c}\text { Fraction Mobile }^{\mathrm{c}} \\
\text { Average (Standard } \\
\text { Deviation) }\end{array}$} & \multirow[b]{2}{*}{$\begin{array}{l}\% \\
\mathrm{ra}^{\mathrm{d}}\end{array}$} & \multirow[b]{2}{*}{$\begin{array}{l}\% \\
\text { bu }\end{array}$} & \multirow[b]{2}{*}{$\begin{array}{l}\% \\
b r\end{array}$} & \multirow[b]{2}{*}{$\begin{array}{l}\% \\
\text { ua }\end{array}$} \\
\hline & & & & & & & & $\left(\mathrm{p} / \mathrm{m}^{2}\right)$ & $\left(\mathrm{m}^{3} / \mathrm{ha}\right)$ & $\left(\mathrm{m}^{3} / 100 \mathrm{~m}\right)$ & & & & & \\
\hline $\begin{array}{l}\text { N.F. Joe Wright } \\
\text { (NFJWC) }\end{array}$ & 9.2 & 0.078 & 14 & 5.0 & 140270 & 44 & 1.67 & 0.12 & 189 & 15.2 & $0.20(0.19)$ & 27 & 6 & 15 & 52 \\
\hline E. St. Louis (ESL) & 9.5 & 0.096 & 65 & 4.3 & 260810 & 47 & 0.31 & 0.32 & 211 & 9.1 & $0.16(0.17)$ & 50 & 18 & 7 & 25 \\
\hline Ouzel (OC) & 13.5 & 0.013 & 52 & 6 & 220360 & 70 & 1.39 & 0.17 & 182 & 10.9 & $0.20(0.17)$ & 64 & 2 & 9 & 25 \\
\hline Loch Vale (LVC) & 20.9 & 0.036 & 13 & 5 & 300480 & 41 & 1.15 & 0.12 & 91 & 4.6 & $0.23(0.16)$ & 52 & 6 & 12 & 30 \\
\hline West Branch (WBC) & 32.3 & 0.027 & 18 & 6.5 & 220430 & 68 & 1.28 & 0.02 & 18 & 1.2 & $0.22(0.18)$ & 61 & 12 & 9 & 18 \\
\hline
\end{tabular}

\footnotetext{
${ }^{a}$ Here $A$, drainage area; $S$, channel gradient; $w_{v}$, valley-bottom width; $w$, reference channel width.

${ }^{\mathrm{b}}$ Wood loading: $\mathrm{p} / \mathrm{m}^{2}$ is (average number of pieces in reach)/(average channel width)(reach length) $=$ number of pieces $/ \mathrm{m}^{2}$ channel. $\mathrm{m}^{3} / \mathrm{ha}$ is cubic meters of wood per hectare of channel, where wood volume is calculated assuming each piece of wood is a cylinder with radius (r) and length (L), such that volume $=\pi \mathrm{r}^{2} \mathrm{~L} \cdot \mathrm{m}^{3} / 100 \mathrm{~m}$ is cubic meters of wood per $100 \mathrm{~m}$ length of channel. All values were averaged over the period of study.

${ }^{c}$ Average and standard deviation values based on the entire period of study.

${ }^{\mathrm{d}}$ Average percent ramps (ra), buried (bu), bridges (br), and unattached (ua) over the period of study.
} 


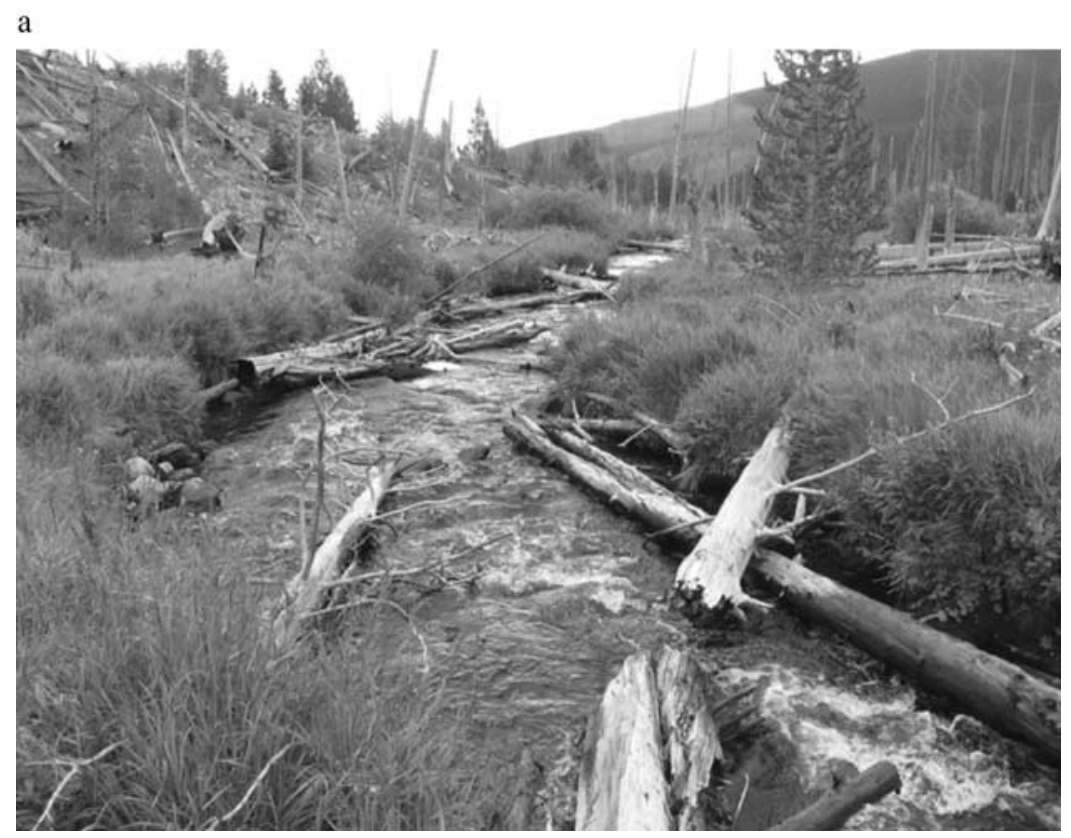

Figure 2. (a) View downstream at the midpoint of the study reach on Ouzel Creek, August 2006. (b) Plan view maps of the distribution of wood along Ouzel Creek for each year of the study. The color of each piece of wood indicates the year in which it entered the study reach. The full extent of each piece beyond the bankfull channel (outlined in light gray) is not shown.

tracer and conductivity probes [Curran and Wohl, 2003]. We used $v$ with surveyed reach-averaged channel width $(w)$ and flow depth $(d)$ to directly calculate the annual peak discharge $(Q=w d v)$ at each site for that year. We also used multiple cross-sectional surveys to calculate a reach-averaged value for hydraulic radius $(R)$ at the reference level. Bed gradient $(S)$ was calculated from a longitudinal thalweg survey. We measured grain-size distribution from 100 clasts selected using a grid across the streambed [Wohl et al., 1996]. These parameters were then used to calculate reach-averaged values of shear stress $(\tau=\gamma R S$, where $\gamma$ is the specific weight of water), unit stream power $(\omega=\Omega / w$, where $\Omega=\gamma Q S)$, and relative submergence $\left(R / D_{84}\right.$, where $D_{84}$ is a measure of the coarse grain size).

[14] Measured wood characteristics include the location and arrangement of wood within the channel surveyed with a laser theodolite, length $\left(L_{l o g}\right)$ and diameter $\left(D_{l o g}\right)$ of inchannel wood measured using a metric tape, and arrangement of each piece of wood within the channel based on four categories. The categories are (1) bridge, for which both ends rest on opposite channel banks above the reference level, (2) ramp, for which one end rests on the bank above the reference level, (3) buried, in which a portion of the wood is buried in streambed sediment, and (4) unattached, with no burial in channel sediment and not resting on either bank above the reference level. Unattached pieces are often lodged against the upstream side or beneath another piece of wood, and are likely deposited during the waning stages of peak flow. Although pieces of wood were not tagged for this study because two study reaches are within Rocky Mountain National Park, detailed surveys, drawings, and photographs were used to relocate individual pieces each year and we are confident of our ability to relocate pieces based on distinguishing features despite the occurrence of breakage and movement (Figure 2b). A piece was considered to be mobile if it left the study reach or changed in arrangement (e.g., a bridge breaking to become two ramps). No attempt was made to relocate pieces that moved downstream beyond a study reach. A more detailed documentation would have required tagging and surveying pieces to document annual travel distance and determine whether initial movement enhances stability. We recommend this method for future studies on wood residence time. We also calculated the mean number of pieces in contact with other pieces (contact) within each reach over the period of study.

\subsection{Statistical Analyses}

\subsubsection{Variable Computation}

[15] Because only the site at East St. Louis Creek was gaged, we assumed that the other four streams received a similar peak each year in relation to all other years (the relative magnitude of each annual peak flow on each of the other four streams was similar to the relative magnitude of each annual peak flow on East St. Louis Creek). This assumption is supported by records from other gaged streams in the region. Rainfall has very limited effect on flows in these high-elevation catchments, and the snowpack and melt rate are consistent throughout the study area, as is the timing of snowmelt peak flow. Mean annual peak snowmelt flow has a strong linear correlation with $A$ [Wohl et al., 2004]. We know the differences among $A$ for the individual study sites, as well as the relative magnitude of peak snowmelt flow during the year in which we directly measured $w, d$, and $v$ at the study sites. Therefore, it seems 

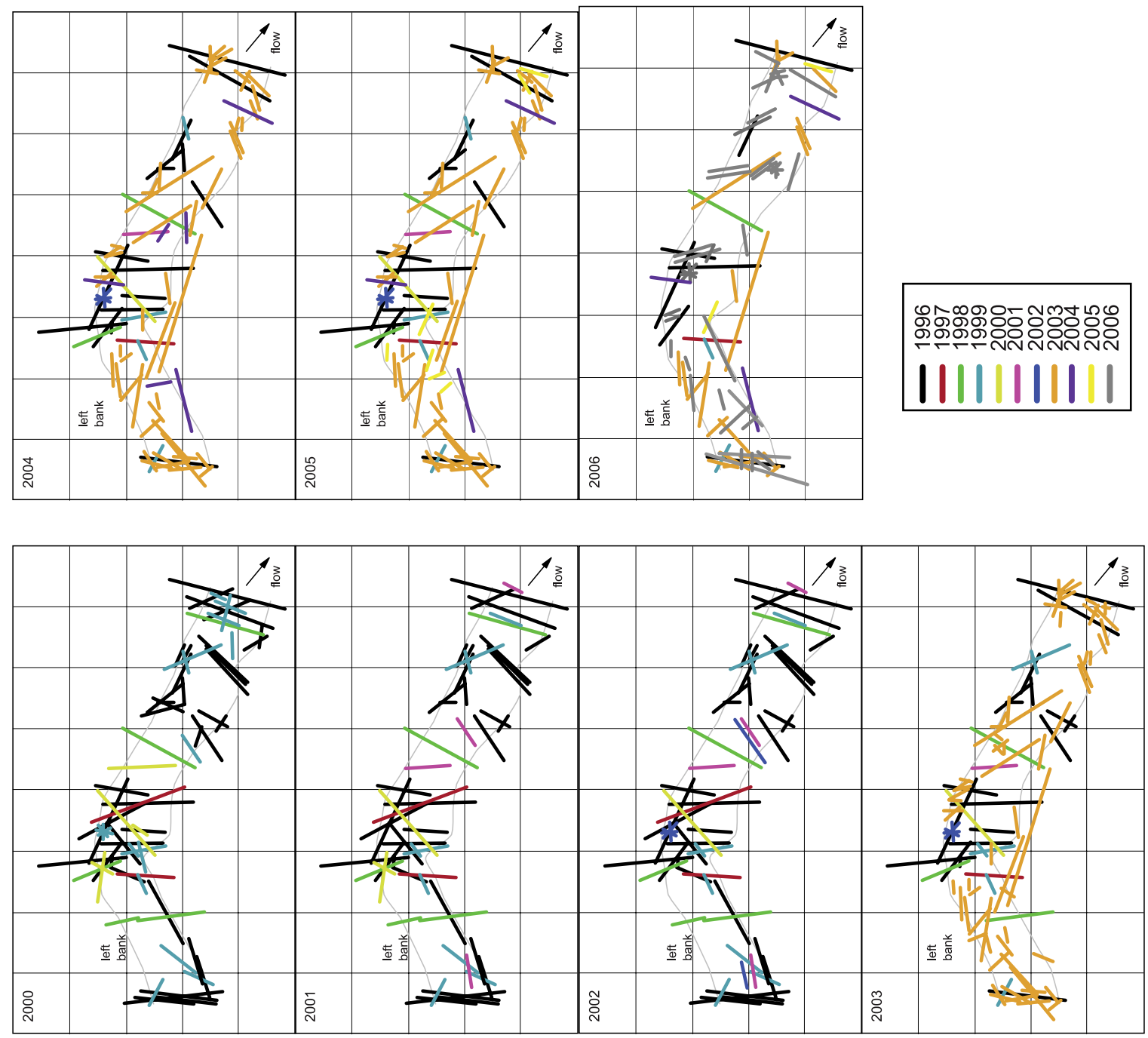

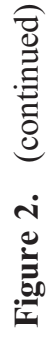
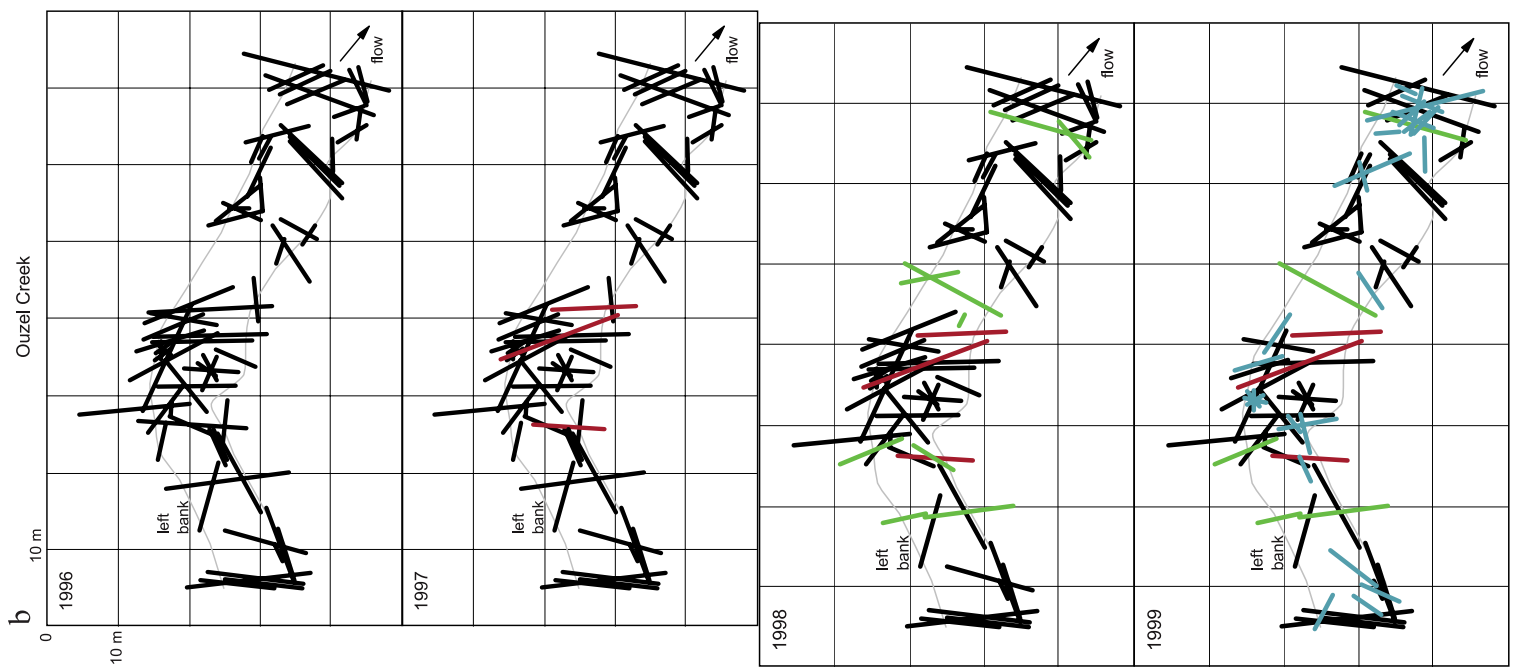
reasonable to assume that the relative magnitude of annual peak flow at the ungaged sites varies in parallel with the relative magnitude at East St. Louis Creek.

[16] In this situation, the variable of calendar year becomes a surrogate for peak discharge. Distinct yearly peak discharges were calculated for the four other streams using the ratio of peak discharge/reference discharge from East St. Louis Creek. For each year this ratio was multiplied by the reference discharge in each stream to yield a yearly peak discharge relative to East St. Louis Creek $\left(Q_{\text {relpeak }}=\right.$ $\left.Q_{b f}\left(Q_{\text {peakESL }} / Q b f E S L\right)\right)$. These relative peak discharges for each stream were used to compute a peak total stream power $\left(\Omega=\gamma Q_{\text {relpeak }} S\right)$.

[17] Previous flume and field studies have documented that dimensionless piece length and diameter are the most important determinants of piece mobility and travel distance [Braudrick and Grant, 2000; Haga et al., 2002; Bocchiola et al., 2008]. Therefore, we created two similar dimensionless ratios: piece length to average reference channel width $\left(L_{\log } *=L_{\log } / w_{a v}\right)$, and annual peak flow depth to piece diameter $\left(D_{\text {log }} *=d_{\text {peak }} / D_{\text {log }}\right)$. The second term is similar to the floating index, $h^{*}\left(h^{*}=D_{\log } *\left(\rho_{w} / \rho_{l o g}\right)\right)$, described by Bocchiola et al. [2006b], with the ratio $\left(\rho_{w} / \rho_{l o g}\right)$ eliminated. Although $\rho_{\log }$ was not measured directly, we did evaluate the effects of a range of $\rho_{\text {log }}$, as summarized in the results. The variable $d_{\text {peak }}$ was computed via continuity from $Q_{\text {relpeak }}$, assuming that $v$ and $w$ at reference flow were similar to peak flow. $L_{\log }{ }^{*}$ and $D_{\log }{ }^{*}$ refer to individual piece dimensions. The variable contact represents the number of other pieces that an individual piece touched each year and is a measure of both the local congestion affecting each piece and whether the piece forms part of a jam (defined here as three or more pieces of wood in contact). This variable does not specifically assess the spatial arrangement of wood in these streams, but instead provides insight into the temporal dimension of wood dynamics.

\subsubsection{Wood Load and Piece Mobility}

[18] Wood load $\left(W_{L}\right)$ was the number of pieces in each reach divided by the product of $w$ and reach length, which equates to number of pieces per square meter of channel, averaged over the period of study. Piece mobility was characterized using the variable percent mobile (\% mobile), which is the percent of total pieces mobile within the reach, averaged over the period of study. The small sample size of five study reaches, and the fact that each basin- or channelscale variable (e.g., $D_{84}$ ) was represented by a single value for each study reach, limited our ability to statistically determine the most important channel and valley characteristics that controlled $W_{L}$ and channel characteristics that controlled \% mobile. Recognizing the limited statistical power, we used simple regressions to evaluate the firstorder channel and valley controls on $W_{L}$ and \% mobile. Channel characteristics $\left(w, S, R / D_{84}, Q, \omega, \tau\right)$ and valley characteristics $\left(w_{v}, D B H\right.$, tree $\left.\rho\right)$ were tested as potential controls on $W_{L}$, whereas only channel characteristics, which would physically drive wood mobility, were tested as potential controls on $\%$ mobile.

\subsubsection{Residence Time}

[19] Residence time $\left(T_{r}\right)$ was calculated as time from year of first observation to first year of absence. Pieces that were present either during the first year of observation or at the end of the study were not included in this calculation of residence time because those residence times extended beyond the study time domain. Because $T_{r}$ was measured at discrete yearly intervals after the peak flow, $T_{r}$ was modeled as a discrete variable.

[20] We employed a statistical method called survival analysis to model the relationships among potential control variables and $T_{r}$. Survival analysis deals with modeling time to event data; in this case, movement of a piece of wood is considered the event. Because this study imposed a time domain over the processes of wood recruitment and transport, we did not have a full record of the dynamics for wood pieces that existed in the study streams at the bounds of the study period. Such observations that continue beyond the time domain and therefore have missing data regarding their residence time are referred to as censored data, which are common in survival analysis. For these censored data, we only know that $T_{r}$ is at least as long as the study period records. Exact residence times were known only for pieces that both entered and exited the study reach during the study period. These pieces, which are considered uncensored data, corresponded to $40 \%$ (264 of 659) of the pieces observed in all five streams during the study period. Survival analysis using censored data produces the best estimates of the median residence time when less than half of the sample is censored. To accommodate this, pieces that entered during the last year of the study were excluded. Excluding pieces that entered in the last year, $48 \%$ of the pieces were censored, which allowed for better estimates and modeling of the true median residence time. In survival analysis, the mean is biased downward when there are censored times greater than the largest $T_{r}$. This means that the upper tail of the distribution will be poorly estimated when a substantial number of cases are censored, which greatly affects estimates of the mean. Therefore the median is a much preferred measure of the central tendency for survival data analysis [Allison, 1995].

[21] The survival analysis was performed with proc PHREG in SAS 9.1.3. This uses the Cox-proportional hazards regression model, which does not require a particular distribution to represent survival times or, in our case, residence times [Cox, 1972]. The basic form of this model is written as,

$$
h_{i}(t)=\lambda_{0}(t) \exp \left\{\beta_{1} x_{i 1}+\ldots+\beta_{k} x_{i k}\right\}
$$

The model states that the hazard, or risk, for individual $i$ at time $t$ is the product of: (1) a baseline hazard function $\lambda_{0}(t)$ that is unspecified, but must be positive, and (2) a linear function of a set of $k$ fixed covariates, exponentiated. The benefit of the Cox-proportional hazards model is that it ignores $\lambda_{0}(t)$ and it treats the second part, the partiallikelihood function, as the ordinary likelihood function. This method obtains parameter estimates that maximize the partial likelihood. The estimates have 2 of the 3 standard properties of the maximum likelihood estimates: They are approximately unbiased and their sampling distribution is approximately normal in large samples. Estimates depend only on the rank of residence times, so that coefficients are not altered by transformations [Allison, 1995]. Ties in $T_{r}$ were dealt with using the exact method, which assumes that time is continuous and that there is a true but unknown order of tied residence times [Allison, 1995]. 

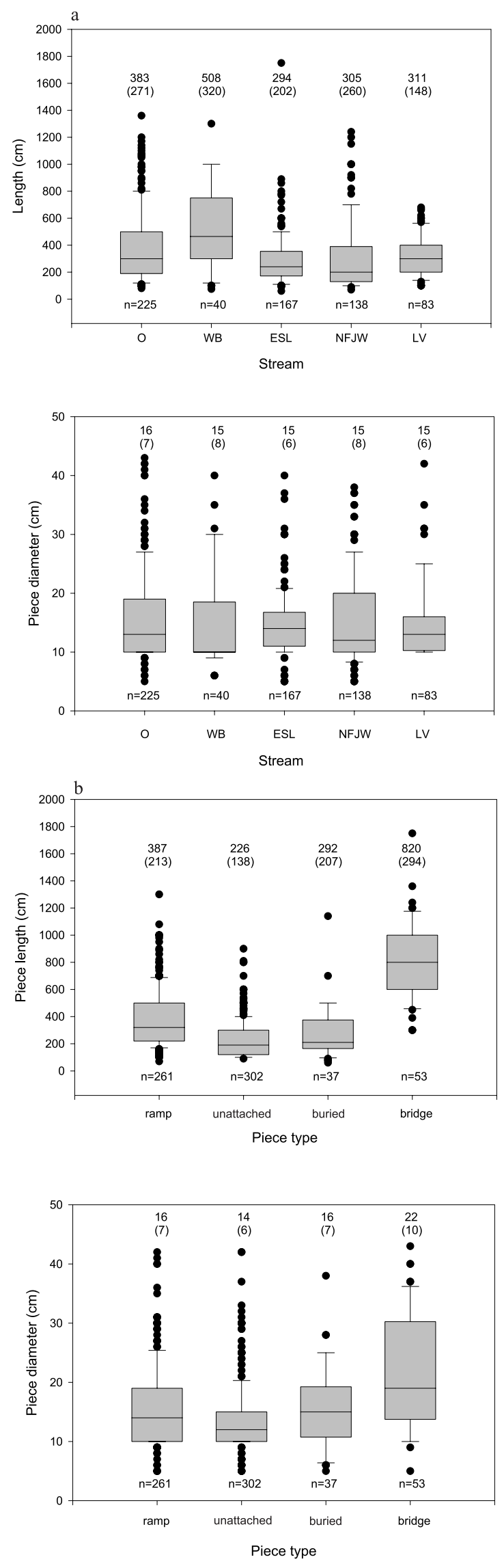

[22] This nonparametric regression analysis was used to test which combination of the following piece and hydraulic variables exerted the strongest control on $T_{r}: L_{l o g}{ }^{*}, D_{l o g}{ }^{*}$, piece type, contact (a time dependent covariate), stream (a categorical predictor to account for other differences among streams such as valley characteristics), mean annual peak discharge (average relative peak discharge for the period of residence), and mean annual peak unit stream power (peak unit stream power averaged over the period of residence). We used forward stepwise and best subsets (minimum AIC) model selection methods to determine the best set of variables controlling the mean piece residence time [Kutner et al., 2005].

\subsubsection{Piece Mobility}

[23] We used multiple logistic regression analysis to test which piece characteristics and hydraulic characteristics exerted the greatest control on the mobility of individual pieces of wood. The same suite of potential control variables was used as in the former analysis. The response variable was binary (mobile or stationary in a given year). Best subsets model selection using the minimum AIC, backward, and forward stepwise selection techniques were employed. All statistical analyses used a significance level of 0.10 .

\section{Results}

\subsection{Wood Characteristics}

[24] Average $D_{\log }$ of $15 \mathrm{~cm}$ and $L_{\log }$ of $3.2 \mathrm{~m}$ mostly varied little between sites, although pieces are significantly longer at the West Branch Creek site (Figure 3a). At all sites, only $17 \%$ of the pieces were longer than the reference channel width. Averaged across all sites, mean $L_{\log }$ of bridges was $8.2 \mathrm{~m}$ (standard deviation $2.9 \mathrm{~m}$ ), ramps $3.9 \mathrm{~m}$ (standard deviation $2.1 \mathrm{~m}$ ), buried $2.9 \mathrm{~m}$ (standard deviation $2.1 \mathrm{~m}$ ), and unattached $2.3 \mathrm{~m}$ (standard deviation $1.4 \mathrm{~m}$ ) (Figure 3b).

\subsection{Wood Load and Percent Mobility}

[25] As noted previously, a sample size of five rivers limited our ability to evaluate relations between potential control variables and $W_{L}$ or piece mobility. Although $W_{L}$ and $\%$ mobile represent a relatively large sample of ten

Figure 3. (a) Box and whisker plots of piece length and diameter at each of the five study sites $(\mathrm{O}$ is Ouzel, WB is West Branch, ESL is East St. Louis, NFJW is North Fork Joe Wright, and LV is Loch Vale). Mean (and standard deviation) shown along upper $x$ axis above each site, and sample size shown along lower $x$ axis below each site. The line within each box indicates the median value, box ends are the 25th and 75th percentiles, whiskers are the 10th and 90th percentiles, and dots are outliers. Piece length along West Branch Creek is significantly different than the other sites, none of which differ from each other $(\alpha=0.10)$. (b) Box and whisker plots of piece length and diameter for four piece types using all data. The line within each box indicates the median value, box ends are the 25th and 75th percentiles, whiskers are the 10th and 90th percentiles, and dots are outliers. Piece length and diameter of bridges is significantly different from all other piece types, none of which differ from each other $(\alpha=0.10)$. 


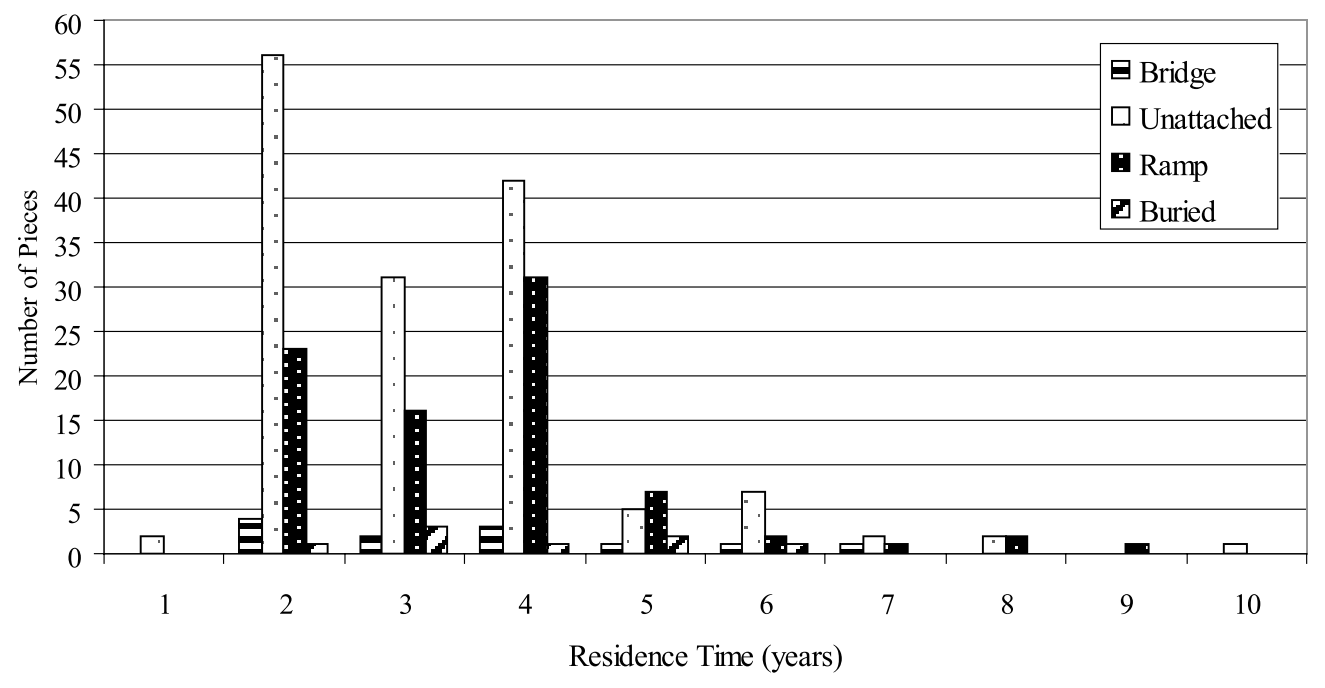

Figure 4. Frequency plot of residence time by piece type. Only pieces that entered and exited during the study period with known residence times are represented. Mean lengths and diameters for each piece type are as follows: bridge $\left(\bar{L}_{\log }=820 \mathrm{~cm}, \bar{D}_{\log }=21 \mathrm{~cm}, n=53\right)$; unattached $\left(\bar{L}_{\log }=226 \mathrm{~cm}, \bar{D}_{\log }=14 \mathrm{~cm}\right.$, $n=304) ; \operatorname{ramp}\left(\bar{L}_{\log }=388 \mathrm{~cm}, \bar{D}_{\log }=16 \mathrm{~cm}, n=259\right)$; sunken $\left(\bar{L}_{\log }=291 \mathrm{~cm}, \bar{D}_{\log }=16 \mathrm{~cm}, n=37\right)$.

years of data for each stream, the sample size of stream predictor variables is too small to test statistical significance. This analysis therefore provides only a first-order examination of the basic trends and correlations in potential control variables.

[26] $W_{L}$ showed a positive linear relationship with $w_{v}\left(\mathrm{R}^{2}=0.70\right)$ and $S\left(\mathrm{R}^{2}=0.49\right)$, and a negative linear relationship with $R / D_{84}\left(\mathrm{R}^{2}=0.58\right)$ and $Q\left(\mathrm{R}^{2}=0.50\right)$. Despite limited statistical power, $w_{v}$ was the only significant linear predictor of $W_{L}(\mathrm{p}=0.07)$. In other words, our analyses suggest that, for the narrowly confined and relatively steep mountain streams examined here, $W_{L}$ increases linearly as $w_{v}$ increases. This might reflect greater recruitment area for trees falling into the channel from the riparian zone, because the steep valley walls at the narrowly confined sites had lower forest-stand density. $W_{L}$ also increases as $S$ increases, and decreases as $R / D_{84}$ and $Q$ increase. These relationships presumably reflect in-channel transport processes, with steep, hydraulically rough channels and lower flows limiting movement of wood.

[27] Percent of pieces mobile in a study reach showed only a mild negative relationship with $\tau\left(\mathrm{R}^{2}=0.35\right)$. The decrease in piece mobility with increasing $\tau$ under reference flow conditions may reflect the fact that steep streams are likely to have a large value of $\tau$, and yet may have limited wood transport because of rough boundaries. That we found only a weak relationship among \% mobile and one of the five channel characteristics examined reflects not only the small sample size, but also the fact that these variables are reach averages, whereas local channel characteristics likely exert greater control on mobility.

\subsection{Residence Time}

[28] $T_{r}$ for wood pieces ranged from 1 to 10 years (Figure 4), with the upper time being limited by the duration of our study. The number of pieces present at the start of the study in 1996 that were still present in 2006 ranged from 1 at Loch Vale Creek through 7 at Ouzel Creek. These values equate to anywhere from $4 \%$ of the total pieces at Loch Vale to $30 \%$ (3 of 10 pieces) at West Branch Creek that have residence times longer than a decade.

[29] Mean $T_{r}$ over all reaches for all years of study was 3.4 years, with a variance of 2.1 years. Means for individual streams ranged from 2.6 years for the West Branch site to 3.9 years for East St. Louis Creek, with no significant differences among streams. A one-way ANOVA comparing mean $T_{r}$ among piece types indicated no significant differences among piece types (range 3.9 years for bridges and buried and 3.3 years for unattached).

[30] The Cox-regression model selection for $T_{r}$ with all pieces considered indicated that the variables of $L_{\log }{ }^{*}$ and $\omega$ were the most significant predictors of mean $T_{r}$ (Table 3 ). This analysis indicates that $T_{r}$ increases as $L_{l o g}{ }^{*}$ decreases, which means that $T_{r}$ increaes as piece length relative to the reference channel width decreases. Decreased residence time for longer pieces is not intuitive, but Braudrick and Grant's [2000] interpretation that longer pieces integrate a wider distribution of the flow field and thus increase the chances of movement, provides some insight. Also, $T_{r}$ increase as $\omega$ increases. Although $L_{\log }{ }^{*}$ was the most important control on $T_{r}$, there were no significant differences in $T_{r}$ among pieces that were longer or shorter than $w$. That lower $\omega$ could create lower mobility, and thus longer $T_{r}$, for wood seems intuitive and confirms the results of earlier flume [Bocchiola et al., 2006a] and field [Young, 1994; Berg et al., 1998; Gurnell et al., 2002] studies.

[31] Decay processes are unlikely to limit the residence time of wood in the study streams over the time span of a decade. With the exception of wood introduced from deciduous tree species such as aspen (Populus tremuloides) and river birch (Betula fontinalis), which decay extremely rapidly, all of the wood was in decay classes 1-4 of Grette's [1985] 7 decay classes. Even the most decayed logs (class 4, bark absent, surface slightly rotted) were sufficiently intact that removal from the study reach was caused by transport of the majority of the piece of wood rather than disintegration in place. Although all pieces of wood from deciduous species were retained in the study sites less than a year, 
Table 3. Model Selection Results for Piece Residence Time and Mobility

\begin{tabular}{|c|c|c|c|c|c|}
\hline Control Variable & $\begin{array}{l}\text { Parameter } \\
\text { Estimate }\end{array}$ & $\begin{array}{c}\text { Standard } \\
\text { Error }\end{array}$ & Chi-Square & $\begin{array}{c}\text { Hazard } \\
\text { Ratio }\end{array}$ & $p$ Value \\
\hline $\begin{array}{l}L_{\log }{ }^{*} \\
\text { Unit stream } \\
\quad \text { power }(\mathrm{W} / \mathrm{m})\end{array}$ & $\begin{array}{c}\text { Cox-Regres } \\
-0.665 \\
-0.002\end{array}$ & $\begin{array}{l}\text { Respon } \\
0.185 \\
0.001\end{array}$ & $\begin{array}{c}\text { ence Time, } R \\
12.943 \\
10.582\end{array}$ & $\begin{array}{l}0.514 \\
0.998\end{array}$ & $\begin{array}{l}0.0003 \\
0.0011\end{array}$ \\
\hline Control Variable & $\begin{array}{l}\text { Parameter } \\
\text { Estimate }\end{array}$ & $\begin{array}{c}\text { Standard } \\
\text { Error }\end{array}$ & Chi-Square & $\begin{array}{l}\text { Odds } \\
\text { Ratio }\end{array}$ & $p$ Value \\
\hline \multicolumn{6}{|c|}{ Multiple Logistic Regression Model: Response $=$ Probability of Mobility, $R^{2}=0.47$} \\
\hline Intercept & 1.418 & $0.19^{\circ}$ & 55.898 & na & $<0.0001$ \\
\hline$L_{\log } *$ & 0.523 & 0.193 & 7.398 & 1.69 & 0.0065 \\
\hline$D_{\log } *$ & 0.049 & 0.029 & 2.689 & 1.052 & 0.005 \\
\hline Type $=$ bridge & -0.0233 & 0.2054 & 0.0129 & 1.032 & 0.9096 \\
\hline Type $=$ unattached & -0.1256 & 0.1224 & 1.0534 & 1.152 & 0.3047 \\
\hline Type $=$ ramp & 0.2038 & 0.1037 & 3.8671 & 1.295 & 0.0492 \\
\hline
\end{tabular}

these pieces made up less than $10 \%$ of the pieces observed in this study. Because the wood introduced from coniferous species was not very decayed, most of the observed movements of pieces came from transport rather than breakage.

\subsection{Piece Mobility}

[32] The best model from logistic regression analyses, based on minimum AIC and parsimony, included $L_{\log } *(\mathrm{p}=$ $0.0065), D_{\log } *(\mathrm{p}=0.005)$, and piece type $(\mathrm{p}=0.081)$. Although $D_{\log }{ }^{*}$ incorporates the peak flow depth as a hydraulic variable, the model results suggest that piece characteristics outweigh hydraulic characteristics as controls on piece mobility. Interpretation of the odds ratios (Table 3) indicates that for a unit increase in $L_{l o g}{ }^{*}$, the odds of mobility are multiplied by 1.69 , assuming constant $D_{\log }{ }^{*}$ and piece type. In other words, an increase in piece length relative to $w$ increases the likelihood that a piece will move, which supports the results noted above for greater $T_{r}$ as $L_{\log }{ }^{*}$ decreases. Also, the odds that a piece will move is multiplied by 1.052 for a unit increase in $D_{\log }{ }^{*}$, assuming constant $L_{\log }{ }^{*}$ and piece type. This means that increasing the floating index, or ratio of peak flow depth to log diameter, leads to a greater likelihood of piece mobility.

[33] By default, the model compared the odds of mobility of buried pieces to all three other types. Examination of these odds ratios suggests that the odds of mobility for bridges (1.032), unattached (1.152) and ramps (1.295) are all greater than for buried pieces.

[34] Although we did not include the ratio $\left(\rho_{w} / \rho_{\text {log }}\right)$ in the calculation of $D_{\log }{ }^{*}$, we did evaluate the potential effects on the mobility analysis of a range of $\rho_{\text {log }}$ for the three dominant species in the study streams. Bocchiola et al. [2008] found a threshold of 1.26 for their floating index $\left(h^{*}=D_{\log } *\left(\rho_{w} / \rho_{\text {log }}\right)\right)$. Above this ratio, most wood moves by floating rather than by rolling. The dry $\rho_{\log }$ for the three dominant species in our study area (spruce, fir and pine) is roughly $500 \mathrm{~kg} / \mathrm{m}^{3}$. Using the dry $\rho_{\text {log }}$ as a low value and $800 \mathrm{~kg} / \mathrm{m}^{3}$ as a high estimate, only $1 \%$ and $10 \%$ of the pieces moved at a floating index less than 1.26 , respectively. Therefore, most of the mobilized wood in these streams likely moved via floating during the annual peak discharge.

\subsection{Additional Observations}

[35] Observations of intact and still partially buried rootwads at the end of some pieces suggest that pieces forming bridges and ramps originate primarily from riparian recruitment rather than transport from upstream. These two piece categories together account for $42-71 \%$ of the total pieces at each reach (Table 2), indicating that local tree fall produces at least half of the wood observed in the study streams.

[36] The years of 2003 and 2006 had the greatest amounts of change in $W_{L}$ at most of the study sites (Figure $2 \mathrm{~b}$ ), with $\%$ mobile ranging from $33 \%$ to $64 \%$ in 2003 and $21 \%$ to $60 \%$ in 2006 . The greatest \% mobile occurred on all streams in 2003, which was the year of greatest peak discharge, but there is no significant linear correlation between \% mobile and $Q$. Both 2003 and 2006 were characterized by an above-average snowpack that melted unusually rapidly because of anomalously warm temperatures during April and May, creating streamflow that peaked earlier than usual and declined rapidly. Much of the change in $W_{L}$ reflected not only pieces leaving each study reach, but also recruitment of new pieces to the channel from the adjacent riparian zone. The number of pieces entering each reach in 2003 ranged from $60 \%$ to $87 \%$ of the average number of pieces present in the reach throughout the study, for 2006 these values were $17 \%$ to $48 \%$. We interpret these unusually large percentages of new pieces to result from a situation in which saturated stream banks were subject to higher rates of erosion and collapse following the rapid recession of peak snowmelt flow.

\section{Discussion}

[37] Piece characteristics ( $L, D$ and type) were the dominant controls on residence time and the likelihood of mobility. We were surprised that longer pieces tended to have the highest degree of mobility and shortest $T_{r}$. This could reflect the fact that: (1) longer pieces span a greater range of hydraulic forces that may enhance mobility [Braudrick and Grant, 2000]; (2) longer pieces may be more susceptible to breakage (recall that breakage in our study was considered mobility; the majority of the pieces that broke were long bridges that broke into two ramps); 
and (3) smaller pieces may be more likely to get trapped in low velocity zones or jams. We did not directly address piece breakage, but simplified our analysis by assuming that once a piece broke, $T_{r}$ was terminated and the resulting pieces became new pieces in the study. We were also surprised that piece submergence, $D_{\log }{ }^{*}$, was not a significant control on $T_{r}$, because other investigators have found a relation between $D_{\log }{ }^{*}$ and travel distance [Braudrick and Grant, 2000; Haga et al., 2002; Bocchiola et al., 2008]. As noted above, we infer that most of the mobilized wood in these streams moved via floating during the annual peak discharge.

[38] Among the most unexpected and therefore striking results from this study was the high degree of mobility and short $T_{r}$ of most of the wood in the study areas. Piece mobility is much higher and $T_{r}$ much shorter than the limited published data indicate for analogously small headwater streams in the Pacific Northwest. At least two characteristics of the Colorado streams could explain these differences; the average dimensions of instream wood pieces relative to channel dimensions, and the volume of wood present on average in the streams.

[39] Gurnell [2003] suggests dividing channels into the three categories of small channels that are narrower than median $L_{l o g}$, medium channels that are narrower than the upper quartile of $L_{l o g}$, and large channels that are wider than the length of all instream wood. Oregon's Mack Creek, for which long-term data on wood mobility are available, is at the small to medium threshold, as are the Colorado streams described here. The median $L_{l o g}$ in Mack Creek is $4-5 \mathrm{~m}$, average $d_{l o g}$ is $0.75 \mathrm{~m}, w$ is $9.1 \mathrm{~m}$, and $d$ is $1.4 \mathrm{~m}$ [Gurnell et al., 2002]. In comparison, the five streams in Colorado had an average $L_{\log }$ of $3.6 \mathrm{~m}$, average $d_{\log }$ of $0.16 \mathrm{~m}, w$ of $5.4 \mathrm{~m}$, and $d$ of $0.5 \mathrm{~m}$. Expressing these values as ratios to facilitate comparison between regions, the average ratio of $L_{\log } / w$ is 0.5 at Mack Creek and 0.65 in the Colorado streams, and the average ratio of $d_{\text {log }} / d$ is 0.5 at Mack Creek and 0.3 in the Colorado streams. These ratios do not seem sufficiently different to explain the greater piece mobility in the Colorado streams. The greater mobility in the Colorado streams is also unlikely to reflect the smaller minimum diameter $(5 \mathrm{~cm})$ for piece inclusion in the study, because we did not find any significant difference in mobility of pieces 5$10 \mathrm{~cm}$ in diameter versus pieces with a diameter of $10 \mathrm{~cm}$ or greater. What differs more dramatically between the two sites is $W_{L}$ and associated congestion.

[40] In 1998, Mack Creek averaged 239 pieces of wood per $100 \mathrm{~m}$ of channel, with some pieces as long as $45 \mathrm{~m}$, although $>65 \%$ were less than $5 \mathrm{~m}$ long [Gurnell et al., 2002]. Almost $80 \%$ of these pieces were in jams of three or more pieces. Each Colorado stream averaged $15-$ 140 pieces $/ 100 \mathrm{~m}$ during the course of this study, with a value of 86 pieces $/ 100 \mathrm{~m}$ when averaged across all five streams. These lower values correspond to global compilations which indicate that, worldwide, coniferous forests produce an average of $240 \mathrm{~m}^{3}$ wood per hectare of channel, whereas streams in the Pacific Northwest average $812 \mathrm{~m}^{3}$ / ha, with input rates of up to 59 pieces/100 m/a [Gurnell, 2003]. Expressed as volume of wood, the Colorado streams are at the lower end of the range reported for streams in conifer forests, averaging $18-211 \mathrm{~m}^{3} / \mathrm{ha}$. Other studies from the region have reported values of $68 \mathrm{~m}^{3} / \mathrm{ha}$
[Nowakowski, 2007] and $140 \mathrm{~m}^{3} / \mathrm{ha}$ [Richmond and Fausch, 1995]. Wood load in the Colorado streams can also be expressed as $\mathrm{m}^{3} / 100 \mathrm{~m}$ of channel. These values average 1.2-15.2, which are within the range of 4.8-54.5 [Bragg et al., 2000], 3.3 [Nowakowski, 2007] and 13.3 [Richmond and Fausch, 1995] reported in previous studies for comparable streams in northern Colorado and Wyoming.

[41] A primary effect of these differences in wood volume stored along stream channels in the Pacific Northwest and the Colorado study sites is the relative lack of congestion in the Colorado streams, where less than $40 \%$ of pieces were in a jam (average range of $2-39 \%$ for the 5 study reaches) and $W_{L}$ values were significantly lower. Other investigators [Gurnell and Sweet, 1998; Bocchiola et al., 2008] have found that inclusion in a jam correlates with decreased wood mobility. Although jams did not appear as a significant influence on wood $T_{r}$ or piece mobility in our statistical analyses, further examination of the data suggests that jams may in fact increase residence time of wood in the study streams. On the three study reaches with the highest wood load - East St. Louis, Ouzel, and North Fork Joe Wright Creeks - the mean $T_{r}$ of wood in a jam was 4.2, 4.5, and 3.4 years, respectively, whereas the mean $T_{r}$ for all wood in those reaches was 3.4, 3.6, and 3.3 years, respectively. In other words, $T_{r}$ for pieces in a jam was up to $25 \%$ longer. The two streams with the smallest $W_{L}$ did not have greater $T_{r}$ for wood in jams. In general, the low volumes of stored wood and relatively small and infrequent jams on the Colorado streams imply that once a piece of wood is mobilized, there are relatively few obstacles to retard its movement and retain it within a short reach of the stream. Wood movement in the Colorado streams is thus highly likely to occur only as uncongested transport [Braudrick et al., 1997].

[42] The smaller values of wood dimensions and volume in the Colorado streams relative to streams in the Pacific Northwest partly reflect differences in climate and forest ecology, and partly reflect historical patterns of land use. Even old-growth conifers growing at the Colorado study sites seldom exceed a diameter of $0.5 \mathrm{~m}$ and a height of $30 \mathrm{~m}$, in comparison to values of 3-4 m diameter and 60$100 \mathrm{~m}$ tall for conifers in the Pacific Northwest. Colorado forests also regenerate more slowly following disturbance, which in the Colorado study area primarily takes the form of wildfire, beetle outbreak, or historical timber harvest [Veblen and Donnegan, 2005]. A simulation model of wood dynamics in streams developed for the Intermountain region of western North America [Bragg et al., 2000], for example, projects more than 200 years after clear-cutting before rates of wood recruitment and storage reach no-harvest levels. The limited historical records available for the condition of streams in the Colorado Front Range prior to extensive timber harvest that began in the early 1860 s and continued through the 1890s also suggest much larger volumes of wood in streams prior to 1860 [James, 1823; Fremont, 1845]. Therefore, the volumes of wood present in the study streams may represent values lower than those commonly present along these rivers prior to 1860 . If this inference is correct, then average residence time of wood pieces may have been greater in the Colorado study streams prior to 1860 .

[43] This leads to issues of temporal representativeness raised by Swanson [2003], who noted that it is appropriate 
to ask whether the patterns observed during any study represent long-term system behavior or a narrow reflection of the most recent events. He also noted that because some rivers have stable properties of wood inputs, whereas others can be quite variable, the strength of inferences drawn from a single sampling varies. Although ten years represents a long period of observation relative to most published studies of instream wood dynamics, knowledge of forest ecology in the Colorado Rockies indicates that rates of wood recruitment likely vary by an order of magnitude or more at time spans of decades to centuries as a result of wildfires and insect outbreaks [Veblen and Donnegan, 2005]. Periods of higher $W_{L}$ presumably correspond to lower rates of mobility and greater residence times. The limited variability in the data set described here does not produce a statistically significant difference in mean $T_{r}$ among streams, but the natural range of temporal variability in $W_{L}$ for the study streams over longer time spans is likely to be much greater than the range of $W_{L}$ directly observed. Based on time since timber harvest, individual streams in this study may represent a low (Loch Vale, West Branch) to medium (Ouzel, N.F. Joe Wright, E. St. Louis) level of $W_{L}$ relative to the range of $W_{L}$ occurring in these streams during the past few hundred years.

[44] Wood load at the Ouzel Creek site is likely to decrease over the next few decades. The 1977 wildfire that burned the site left numerous standing dead trees that gradually fell into the channel during the 1996-2006 study period. Almost all of the standing dead trees have now fallen, and conifers that have germinated since the fire are mostly less than $3 \mathrm{~m}$ in height (Figure 2b). Transport of wood from upstream is likely to be limited to smaller pieces.

[45] Spatial representativeness is also important, as indicated by limited studies of wood budgets that reveal a high degree of spatial variability in $W_{L}$ driven by along- and across-stream differences in recruitment and transport processes [Benda et al., 2003]. An ongoing study of spatial distribution in stream segments greater than $1 \mathrm{~km}$ in length in the study area [Wohl and Jaeger, 2007] indicates that $W_{L}$ in successive 25-m-long reaches of stream varies widely, from a factor of 10 on some smaller streams with relatively uniform longitudinal distribution of wood, to a factor of 900 on other, larger streams where wood is found primarily in large jams widely separated by portions of the stream containing very little wood. Stream segments characterized for the spatial distribution study included the sites on East St. Louis, North Fork Joe Wright, and Ouzel Creeks discussed in this paper. $W_{L}$ in successive 25-m-long reaches along these three creeks varied by factors of 10, 412, and 464 , respectively. The much shorter stream segments discussed in this paper were chosen to be representative of the streams along which they occur, with respect to $w, S$, and $W_{L}$, but more extensive measurements of $W_{L}$ will be necessary to fully characterize spatial variability in $W_{L}$ and $T_{r}$ in headwater streams of the Colorado Rocky Mountains. Harmon et al. [1986] found that wood biomass in unmanaged channels in coniferous forests other than redwood ranged from 200 to $1,000 \mathrm{~m}^{3} / \mathrm{ha}$. Compilations of the more limited data available for the semiarid Intermountain western U.S. indicate that $W_{L}$ ranges from 68 to $140 \mathrm{~m}^{3} / \mathrm{ha}$ [Nowakowski, 2007]. The data from the study streams discussed here mostly fall within this range, suggesting that they may provide spatially representative data on moderate levels of wood load for unmanaged streams in the region.

[46] The geomorphic and ecological effects of short residence times of wood in the Colorado study streams may be partly offset by the fact that $W_{L}$ and the location of individual logjams remain relatively constant at time intervals of a decade or longer in the absence of major disturbance such as wildfire, insect outbreak, or large flood. Therefore, although individual pieces of wood are exchanged, some geomorphic and ecological effects of wood, including storage of sediment, organic matter, and solutes, boundary hydraulic roughness, localized scour of bed and banks, overhead cover for fish, and substrate diversity for macroinvertebrates, may be maintained at relatively constant levels over time spans of a decade or longer. Other effects will be sensitive to relatively frequent wood movement. Biofilms on sediment stored in place for multiple years may function differently as food resources for benthic macroinvertebrates, for example, than does freshly deposited fine sediment. During times of substantially higher $W_{L}$ and thus longer $T_{r}$, more persistent instream wood may create greater sediment storage and channel complexity associated with lateral channel movement and substrate diversity [Montgomery et al., 2003a, 2003b]. Because individual pieces of wood are not necessarily retained very long in the study streams, management that involves introducing or removing wood has to consider the temporary effects of artificial wood manipulation. The most effective wood management strategies will include a continuing source of natural wood recruitment from tree fall and upstream transport.

\section{Conclusions}

[47] The results discussed in this paper support some of our initial expectations. We expected $T_{r}$ to reflect piece characteristics ( $L, d$, type) and hydraulic variables. As expected, buried pieces are least mobile, $W_{L}$ is inversely correlated with mean annual peak discharge, and likelihood of mobility increases as $\omega$ decreases. We did not, however, expect pieces that are longer relative to channel width to be more mobile. We expected residence time to be at least as long as sites in the Pacific Northwest. Average $T_{r}$ of wood in the study streams is unexpectedly short, at 3.4 years, although some pieces of wood are certainly retained for more than a decade. We expected piece characteristics to be the dominant control on likelihood of mobility and piece residence time. $L_{\log }$ appears to be a more significant influence on mobility and residence time than $D_{\text {log }}$, piece type, or congestion in streams of the arid Intermountain West. $D_{\log }$ has a smaller range of variability than streams in the Pacific Northwest, and the relatively low values of $W_{L}$ or the limited sample size may prevent jams from appearing as statistically significant controls on wood mobility. Under these conditions, the relative importance of $L_{\log }$ suggests that management designed to insure a continuing supply of naturally recruited wood to such streams should focus on conserving and restoring patches of riparian forests of sufficient maturity to produce instream wood greater than $3 \mathrm{~m}$ in length through tree fall into the channel.

[48] Acknowledgments. Many graduate students at Colorado State University assisted with field work for this project over the years; we thank 
Dan Cenderelli, Janet Curran, Dave Merritt, Nancy Steinberger, Doug Thompson, and Carolyn Trayler for their work at the field sites. Comments by three anonymous reviewers improved the manuscript.

\section{References}

Abbe, T. B., and D. R. Montgomery (1996), Large woody debris jams, channel hydraulics and habitat formation in large rivers, Reg. Rivers Res. Manage., 12, 201-221.

Allison, P. D. (1995), Survival analysis using the SAS system: A practical guide, 292 pp., SAS Inst. Inc., Cary, N. C.

Benda, L., D. Miller, J. Sias, D. Martin, R. Bilby, C. Veldhuisen, and T. Dunne (2003), Wood recruitment processes and wood budgeting, in The Ecology and Management of Wood in World Rivers, Proceedings of American Fisheries Society Symposium, vol. 37, edited by S. V. Gregory, K. L. Boyer, and A. M. Gurnell, pp. 49-73, Bethesda, Md.

Benke, A. C., and J. B. Wallace (1990), Wood dynamics in the Coastal Plain blackwater streams, Can. J. Fish. Aquat. Sci., 47, 92-99.

Berg, N., A. Carlson, and D. Azuma (1998), Function and dynamics of woody debris in stream reaches in the central Sierra Nevada, California, Can. J. Fish. Aquat. Sci., 55, 1807-1820.

Bilby, R. E., and J. W. Ward (1989), Changes in characteristics and function of woody debris with increasing size of streams in western Washington, Trans. Am. Fish. Soc., 118, 368-378.

Bisson, P. A., R. E. Bilby, M. D. Bryant, C. A. Dolloff, G. B. Grette, R. A. House, M. L. Murphy, K. V. Koski, and J. R. Sedell (1987), Large woody debris in forested streams in the Pacific Northwest: Past, present, and future, in Streamside Management: Forestry and Fishery Implications, contribution 57, edited by E. O. Salo and T. W. Cundy, pp. 143-190, Inst. of For. Resour., Univ. of Wash, Seattle.

Bocchiola, D., M. C. Rulli, and R. Rosso (2006a), Transport of large woody debris in the presence of obstacles, Geomorphology, 76, 166-178.

Bocchiola, D., M. C. Rulli, and R. Rosso (2006b), Flume experiments on wood entrainment in rivers, Adv. Water Resour., 29(8), 1182-1195.

Bocchiola, D., M. C. Rulli, and R. Rosso (2008), A flume experiment on the formation of wood jams in rivers, Water Resour. Res., 44, W02408, doi:10.1029/2006WR005846.

Bragg, D. C., J. L. Kershner, and D. W. Roberts (2000), Modeling large woody debris recruitment for small streams of the central Rocky Mountains, Gen. Tech. Rep. RMRS-GTR-55, Rocky Mountain Res. Station, U. S. Dep. of Agric., Fort Collins, Colo.

Braudrick, C. A., and G. E. Grant (2000), When do logs move in rivers?, Water Resour. Res., 36, 571-583.

Braudrick, C. A., G. E. Grant, Y. Ishikawa, and H. Ikeda (1997), Dynamics of wood transport in streams: A flume experiment, Earth Surf. Process. Landf., 22, 669-683.

Brummer, C. J., T. B. Abbe, J. R. Sampson, and D. R. Montgomery (2006), Influence of vertical channel change associated with wood accumulations on delineating channel migration zones, Washington, USA, Geomorphology, 80, 295-309.

Carlson, J. Y., C. W. Andrus, and H. A. Froehlich (1990), Woody debris, channel features, and macroinvertebrates of streams with logged and undisturbed riparian timber in northeastern Oregon, USA, Can. J. Fish. Aquat. Sci., 47, 1103-1111.

Collins, B. D., D. R. Montgomery, and A. D. Haas (2002), Historical changes in the distribution and functions of large wood in Puget Lowland rivers, Can. J. Fish. Aquat. Sci., 59, 66-76.

Cox, D. R. (1972), Regression models and life tables, J. R. Stat. Soc., B34, $187-220$.

Curran, J. H., and E. E. Wohl (2003), Large woody debris and flow resistance in step-pool channels, Cascade Range, Washington, Geomorphology, 51, 141- 157 .

Fausch, K. D., and T. G. Northcote (1992), Large woody debris and salmonid habitat in a small coastal British Columbia stream, Can. J. Fish. Aquat. Sci., 49, 682-693.

Fausch, K. D., and M. K. Young (2004), Interactions between forests and fish in the Rocky Mountains of the USA, in Fishes and Forestry: Worldwide Watershed Interactions and Management, edited by T. G. Northcote and G. F. Hartman, pp. 463-484, Blackwell Sci, Oxford.

Faustini, J. M., and J. A. Jones (2003), Influence of large woody debris on channel morphology and dynamics in steep, boulder-rich mountain streams, western Cascades, Oregon, Geomorphology, 51, 187-205.

Fremont, J. C. (1845), Report of the exploring expedition to the Rocky Mountains in the year 1842, and to Oregon and North California in the years 1843-'44, Gales and Seaton, Washington, D. C.

Gregory, K. J., A. M. Gurnell, and C. T. Hill (1985), The permanence of debris dams related to river channel processes, Hydrol. Sci. J., 30, 371-381.
Gregory, S. (1991), Spatial and temporal patterns of woody debris retention and transport, Bull. N. Am. Benthol. Soc., 8, 75.

Grette, G. B., (1985), The role of large organic debris in juvenile salmonid rearing habitat in small streams, M. S. thesis, Univ. of Wash., Seattle.

Gurnell, A. M. (2003), Wood storage and mobility, in The Ecology and Management of Wood in World Rivers, Proceedings of American Fisheries Society Symposium, vol. 37, edited by S. V. Gregory, K. L. Boyer, and A. M. Gurnell, pp. 75-91, Bethesda, Md.

Gurnell, A. M., and R. Sweet (1998), The distribution of large woody debris accumulations and pools in relation to woodland stream management in a small, low-gradient stream, Earth Surf. Process. Landf., 23, $1101-1121$.

Gurnell, A. M., H. Piégay, F. J. Swanson, and S. V. Gregory (2002), Large wood and fluvial processes, Freshwater Biol., 47, 601-619.

Haga, H., T. Kumagai, K. Otsuki, and S. Ogawa (2002), Transport and retention of coarse woody debris in mountain streams: An in situ field experiment of $\log$ transport and a field survey of coarse woody debris distribution, Water Resour. Res., 38(8), 1126, doi:10.1029/ 2001WR001123.

Harmon, M. E., et al. (1986), Ecology of coarse woody debris in temperate ecosystems, Adv. Ecol. Res, 15, 133-302.

Heede, B. H. (1972), Influences of a forest on the hydraulic geometry of two mountain streams, Water Resour. Bull., 8, 523-530.

Hyatt, T. L., and R. J. Naiman (2001), The residence time of large woody debris in the Queets River, Washington, USA, Ecol. Appl., 11, 191-202.

Jackson, C. R., and C. A. Sturm (2002), Woody debris and channel morphology in first- and second-order forested channels in Washington's coast ranges, Water Resour. Res., 38(9), 1177, doi:10.1029/ 2001 WR001138.

James, E. (1823), Account of an Expedition From Pittsburgh to the Rocky Mountains, H. C. Carey and I. Lea, Philadelphia, Pa.

Kutner, M. H., C. J. Nachtsheim, J. Neter, and W. Li (2005), Applied Linear Statistical Models, 5th ed., 1396 pp., McGraw-Hill, Irwin, New York.

Lawrence, D. E. (1991), Woody debris budgets in "burn" and "reference" headwater streams: Long-term predictions for debris accumulation processes and geomorphic heterogeneity [abstract], Bull. N. Am. Benthol. Soc., 8, 75 .

Lienkaemper, G. W., and F. J. Swanson (1987), Dynamics of large woody debris in old-growth Douglas-fir forests, Can. J. For. Res., 17, 150-156.

MacFarlane, W. A., and E. E. Wohl (2003), Influence of step composition on step geometry and flow resistance in step-pool streams of the Washington Cascades, Water Resour. Res., 39(2), 1037, doi:10.1029/ 2001 WR001238.

Malanson, G. P., and D. R. Butler (1990), Woody debris, sediment, and riparian vegetation of a subalpine river, Montana, USA, Arct. Alp. Res., $22,183-194$.

Marcus, W. A., R. A. Marston, C. R. Colvard, and R. D. Gray (2002), Mapping the spatial and temporal distributions of woody debris in streams of the Greater Yellowstone Ecosystem, USA, Geomorphology, 44, 323-335.

Montgomery, D. R., and T. B. Abbe (2006), Influence of logjam-formed hard points on the formation of valley-bottom landforms in an oldgrowth forest valley, Queets River, Washington, USA, Quat. Res., 65, $147-155$.

Montgomery, D. R., B. D. Collins, J. M. Buffington, and T. B. Abbe (2003a), Geomorphic effects of wood in rivers, in The Ecology and Management of Wood in World Rivers, Proceedings of American Fisheries Society Symposium, vol. 37, edited by S. V. Gregory, K. L. Boyer, and A. M. Gurnell, pp. 21-47, Bethesda, Md.

Montgomery, D. R., T. M. Massong, and S. C. S. Hawley (2003b), Influence of debris flows and log jams on the location of pools and alluvial channel reaches, Oregon Coast Range, Geol. Soc. Am. Bull., 115, 78-88.

Murphy, M. L., and K. V. Koski (1989), Input and depletion of woody debris in Alaska streams and implications for streamside management, N. Am. J. Fish. Manage., 9, 427-436.

Nowakowski, A. (2007), Mapping wood distributions in mountain streams, Bighorn National Forest, Wyoming, M. S. thesis, 89 pp., Colo. State Univ., Fort Collins.

Richmond, A. D., and K. D. Fausch (1995), Characteristics and function of large woody debris in subalpine Rocky Mountain streams in northern Colorado, Can. J. Fish. Aquat. Sci., 52, 1789-1802.

Swanson, F. J. (2003), Wood in rivers: A landscape perspective, in The Ecology and Management of Wood in World Rivers, Proceedings of American Fisheries Society Symposium, vol. 37, edited by S. V. Gregory, K. L. Boyer, and A. M. Gurnell, pp. 299-313, Bethesda, Md.

Tweto, O. (1979), Geologic map of Colorado, 1:500000 scale, U. S. Geol. Surv., Denver, Colo. 
Veblen, T. T., and J. A. Donnegan (2005), Historical range of variability for forest vegetation of the national forests of the Colorado Front Range, 151 pp., For. Serv. Rocky Mountain Region, U. S. Dep. of Agric., Golden, Colo.

Wohl, E., and K. Jaeger (2007), Longitudinal distribution of wood along headwater streams in the Colorado Front Range, Eos Trans. $A G U$, 88(52), Fall Meet. Suppl., Abstract H42A-04.

Wohl, E. E., D. J. Anthony, S. W. Madsen, and D. M. Thompson (1996), A comparison of surface-sampling methods for coarse fluvial sediments, Water Resour. Res., 32, 3219-3226.

Wohl, E. E., S. Madsen, and L. MacDonald (1997), Characteristics of log and clast bed-steps in step-pool streams of northwestern Montana, USA, Geomorphology, 20, 1-10.
Wohl, E., J. N. Kuzma, and N. E. Brown (2004), Reach-scale channel geometry of a mountain river, Earth Surf. Process. Landf., 29, 969-981. Young, M. K. (1994), Movement and characteristics of stream-borne coarse woody debris in adjacent burned and undisturbed watersheds in Wyoming, Can. J. For. Res., 24, 1933-1938.

Zelt, R. B., and E. E. Wohl (2004), Channel and woody debris characteristics in adjacent burned and unburned watersheds a decade after wildfire, Park County, Wyoming, Geomorphology, 57, 217-233.

J. R. Goode and E. Wohl, Department of Geosciences, Colorado State University, Fort Collins, CO 80523, USA. (ellenw@cnr.colostate.edu) 